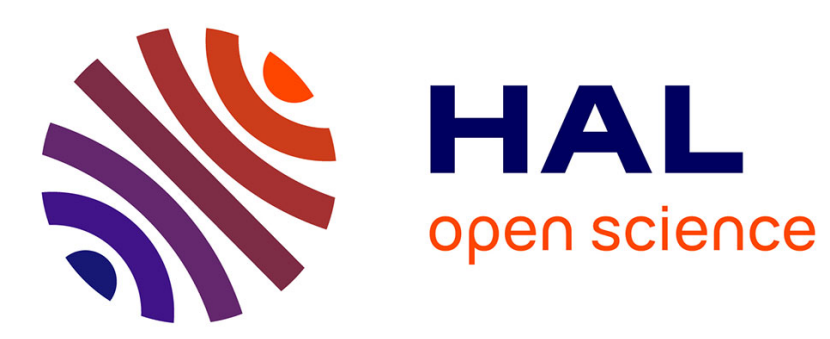

\title{
Cell cycle regulation during early mouse embryogenesis.
} Jérôme Artus, Michel Cohen-Tannoudji

\section{To cite this version:}

Jérôme Artus, Michel Cohen-Tannoudji. Cell cycle regulation during early mouse embryogenesis.. Molecular and Cellular Endocrinology, 2008, 282 (1-2), pp.78-86. 10.1016/j.mce.2007.11.008 . pasteur-00385488

\section{HAL Id: pasteur-00385488 \\ https://hal-pasteur.archives-ouvertes.fr/pasteur-00385488}

Submitted on 19 May 2009

HAL is a multi-disciplinary open access archive for the deposit and dissemination of scientific research documents, whether they are published or not. The documents may come from teaching and research institutions in France or abroad, or from public or private research centers.
L'archive ouverte pluridisciplinaire HAL, est destinée au dépôt et à la diffusion de documents scientifiques de niveau recherche, publiés ou non, émanant des établissements d'enseignement et de recherche français ou étrangers, des laboratoires publics ou privés. 

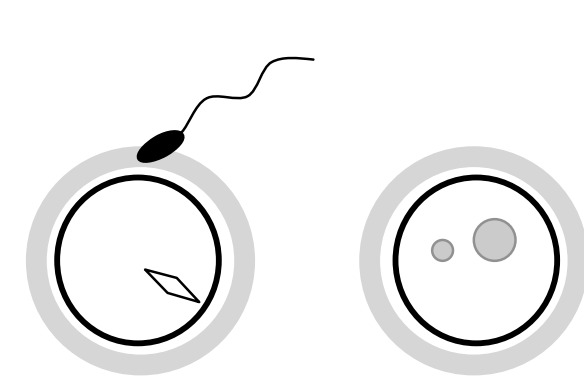

hCG injection

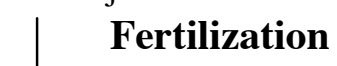

$\checkmark$

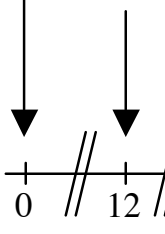

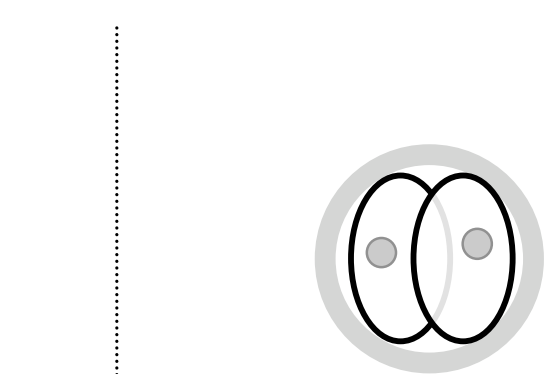

Zygotic Genome Activation
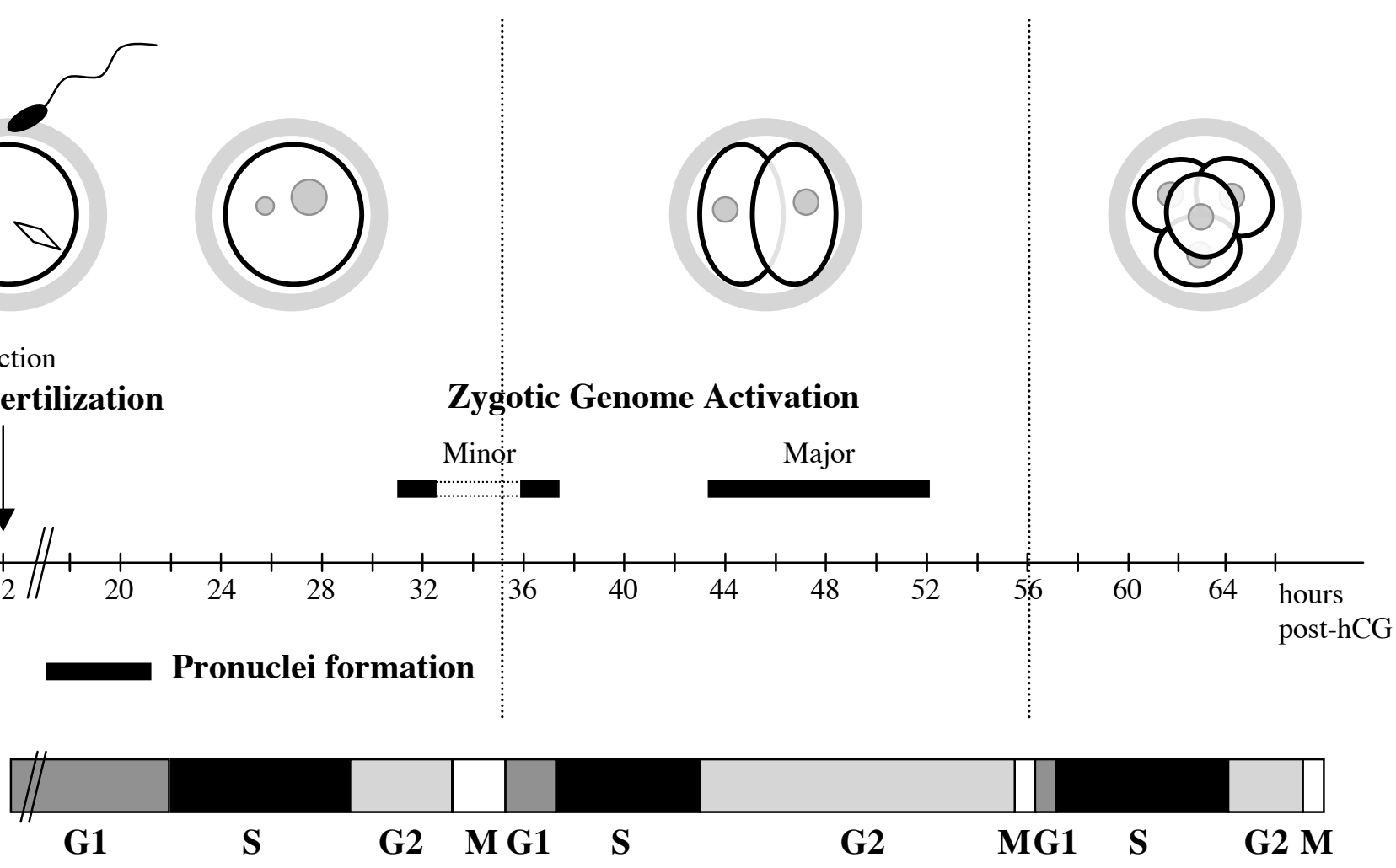


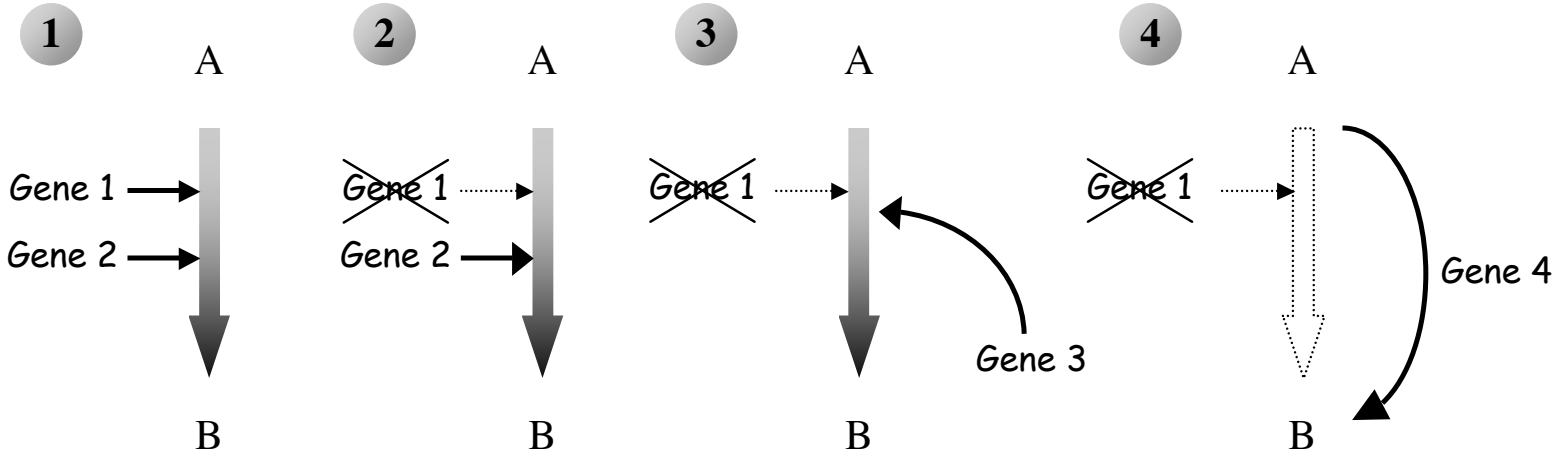




\begin{tabular}{|c|c|c|c|c|c|c|c|c|c|c|c|c|}
\hline \multicolumn{3}{|c|}{$1^{\text {st }}$ division } & \multicolumn{3}{|c|}{$2^{\mathrm{d}}$ division } & \multicolumn{3}{|c|}{$3^{\text {rd }}$ division } & \multicolumn{3}{|c|}{$4^{\text {th }}$ division } & \multirow{2}{*}{ References } \\
\hline G1 & $\mathrm{S}$ & G2 $\mathrm{M}$ & G1 & $\mathrm{S}$ & G2 $\mathrm{M}$ & G1 & $S$ & G2 $\mathrm{M}$ & G1 & S & G2 M & \\
\hline \multirow{10}{*}{$\begin{array}{l}4 \\
9 \\
8\end{array}$} & 4 & $3-5$ & & & & & & & & & & [6] \\
\hline & $6-7$ & 5 & & & & & & & & & & [121] \\
\hline & 4 & & & & & & & & & & & [7] \\
\hline & $7-8$ & & & & & & & & & & & [122] \\
\hline & 4 & 8 & 0.5 & 7 & 11.5 & 1 & 7 & 2 & & & & [3] \\
\hline & 5 & 5 & 2 & 6 & 14 & 1 & 7 & & & & & [3] \\
\hline & & & 1 & 4 & & & & & & & & [123] \\
\hline & & & & 6 & 12 & & & & & & & [10] \\
\hline & & & 1.3 & 6.1 & $15.4 \quad 1.3$ & 1.6 & 7.4 & $0.5 \quad 1.2$ & & & & [12] \\
\hline & & & & & & 1 & 7 & $2-5$ & 2 & 7 & $1-3$ & [124] \\
\hline 7 & 5.3 & 6.5 & 1.2 & 5.8 & 13.5 & 1.1 & 7.1 & 2.9 & & 7 & 3 & Average \\
\hline & 1 & 9 & & & 0 & & & 11 & & & 1 & Total lenght \\
\hline
\end{tabular}




\begin{tabular}{ccccccc}
\hline Embryonic layer & G1 & S & G2 & M & Total & Reference \\
\hline Ectoderm & 0.25 & 4 & 0.5 & $1.5 \mathrm{~h}$ & $\mathbf{6 . 2 5}$ & {$[24]$} \\
& $1.5-2$ & $3.5-4$ & $<0.7$ & $0.75 \mathrm{~h}$ & $\mathbf{7 - 7 . 5}$ & {$[22]$} \\
Mesoderm & 0.7 & 5 & 0.5 & 1.3 & $\mathbf{7 . 5}$ & {$[24]$} \\
& $1.5-2$ & $3.5-4$ & $<0.7$ & 0.75 & $\mathbf{7 - 7 . 5}$ & {$[22]$} \\
Proliferative zone & $<0.5$ & $2-2,75$ & $<0.3$ & 0.75 & $\mathbf{3 - 3 . 5}$ & {$[22]$} \\
& & & & & $\mathbf{3 . 6}$ & {$[23]$} \\
\hline
\end{tabular}

